\title{
PENGARUH METODE PENGAMBILAN MINYAK ATSIRI DARI DAUN JERUK PURUT (Citrus hystrix) TERHADAP KANDUNGAN GERANIOL DAN SITRONELAL
}

\author{
Silvia Rahmi Ekasari \\ Jurusan Tadris Kimia, Fakultas Tarbiyah dan Ilmu Keguruan, IAIN Tulungagung \\ Jl. Mayor Sujadi Timur No. 56, Tulungagung. \\ Email: silvia.zamzami@gmail.com
}

\begin{abstract}
Abstrak
Minyak atsiri yang berasal dari daun jeruk purut disebut combava petitgrain banyak digunakan dalam industri makanan, minuman, farmasi, flavor, parfum, pewarna dan lain-lain. Misalnya dalam industri pangan banyak digunakan sebagai pemberi cita rasa dalam produkproduk olahan. Sifat tersebut disebabkan kandungan zat aktif aromatis di dalamnya. Jika zat atau komponen aktif tersebut dipisahkan dengan cara diekstrak, baik dengan pelarut tertentu (misalnya etanol dan n-heksan)maupun penyulingan (destilasi) hasilnya masing-masing dikenal dengan nama oleoresin atau minyak atsiri. Dalam percobaan ini dilakukan proses pengambilan minyak atsiri dengan metode destilasi uap, destilasi air, dan ekstraksi soxhlet menggunakan pelarut $n$-heksan dalam skala laboratorium serta menganalisa kadar geraniol dan sitronelal dalam minyak atsiri daun jeruk purut (Citrus hystrix). Dari hasil percobaan dapat diketahui bahwa lama penyulingan dan cara pengambilan minyak atsiri dari daun jeruk purut memberi pengaruh nyata terhadap rendemen, densitas, total geraniol dan total sitronelal; lama penyulingan yang terlalu lama (di atas 2,5 jam) dengan jumlah bahan $50 \mathrm{gr}$ akan menurunkan mutu rendemen yang dikehendaki; Minyak daun jeruk purut dalam penelitian ini memenuhi standart mutu eksport, menghasilkan rendemen 1,336 - 1,522 dengan kandungan geraniol 0,89 - 2,21\% dan sitronelal 5,44 - 7,29\%.
\end{abstract}

Kata kunci: daun jeruk purut, destilasi uap, destilasi air, ekstraksi, geraniol, sitronelal.

\section{PENDAHULUAN}

Minyak atsiri atau "minyak eteris" adalah istilah yang digunakan untuk minyak mudah menguap dan diperoleh dari tanaman dengan cara penyulingan uap. Definisi ini, dimaksudkan untuk membedakan minyak/lemak dengan minyak atsiri yang berbeda tanaman penghasilnya. Definisi ini akan lebih lengkap jika ke dalam kelompok ini dicantumkan pula minyak yang mudah menguap dengan metode ekstraksi yaitu dengan cara menggunakan penyulingan uap (Ketaren, 1978).

Selama ini para pekebun di Indonesia hampir tidak punya pilihan untuk mengatasi kelebihan produksi, selain menjual daunnya. Namun setelah diketahui berbagai kandungan dalam daun jeruk purut (Citrus hystrix) yang memiliki banyak sekali manfaat dalam berbagai bidang, maka berlimpahnya daun jeruk purut pada saat musim panen dapat diatasi dengan cara pembuatan minyak atsiri dari daun jeruk purut. Harga ekstrak minyak daun jeruk relatif mahal. Proses Ekstraksi minyak daun jeruk purut dapat dikerjakan dengan metode sederhana dengan menggunakan peralatan yang tidak terlalu mahal.
Jika daun jeruk purut itu disuling, dihasilkan minyak atsiri yang tidak berwarna (bening) sampai kehijauan, berbau harum seperti bau daunnya.

Komponen kimia dalam minyak daun jeruk purut sangat komplek, namun komponen yang terpenting adalah sitronelal dan geraniol. Perbedaan kandungan kimia dalam minyak akan menyebabkan perbedaan dalam kehalusan dan kelembutan aromanya. Semakin lembut dan halus aromanya maka semakin tinggi kandungan geraniol, sitronelal, hidroksi sitronelal, linalol dan linalil asetat (Koswara, 2011).

Geraniol $\left(\mathrm{C}_{10} \mathrm{H}_{18} \mathrm{O}\right)$ adalah monoterpenealkohol asiklik yang merupakan persenyawaan yang terdiri dari dua molekul isoprene dan satu molekul air. Geraniol murni adalah cairan berminyak dan tidak berwarna dengan aroma yang khas. Bila dioksidasi akan menjadi geranial atau citral.

Penyebab bau utama pada minyak daun jeruk purut adalah sitronelal, yang merupakan bahan dasar untuk pembuatan parfum, oleh karena itu minyak daun jeruk purut dengan kadar sitronelal tinggi akan lebih baik kualitasnya. Jenis minyak yang demikian akan diperoleh dari fraksi pertama penyulingan. 
Sitronellal memiliki aktivitas antibakteri yang dapat menghambat pertumbuhan Salmonella dan Enterobakteria lainnya (Nanasombat, 2005) dan aktivitas antioksidan (Ayusuk dkk., 2009).

Standar mutu minyak daun jeruk purut untuk kualitas eksport dapat dianalisa menurut kriteria fisik yaitu berdasarkan warna, bobot jenis, indeks bias, ataupun secara kimia berdasarkan total geraniol dan sitronelal. Oleh karena itu perlu diketahui dengan metode apa yang paling efektif untuk menghasilkan minyak atsiri dengan kadar sitronelal dan geraniol sehingga minyak atsiri yang dihasilkan dapat masuk ke pasar ekspor dunia (Kapoor dan Krishan, 1977).

\section{METODOLOGI}

Dalam percobaan ini akan mengetahui proses pengambilan minyak atsri dengan metode destilasi uap, destilasi air, dan ekstraksi soxhlet dalam skala laboratorium dengan variable waktu 1,2 dan 3 jam serta menganalisa kadar geraniol dan sitronelal dalam minyak atsiri daun jeruk purut (Citrus hystrix). Daun jeruk purut, air dan pelarut yang digunakan adalah daun jeruk purut 50 gr, Air (labu uap) $500 \mathrm{ml}$ dan pelarut (n-heksan) : $200 \mathrm{ml}$.

Analisa geraniol dengan standart pengujian : SNI 06-0027-1987 sedangkan sitronelal dengan standart pengujian : SNI 06-0026-1987.

Destilasi uap dilakukan secara langsung dengan melakukan penyulingan menggunakan uap. Pada cara ini, ketel uap dipisahkan dari ketel penyuling yakni ketel yang berisi bahan. Uap yang dihasilkan padaketel uap, dialirkan pada sebuah pipa ke dalam ketel penyuling. Uap jernih yang dihasilkan (dengan tekanan kurang dari 1 atmosfir) dialirkan kedalam ketel penyuling. Bersama uap air ini, minyak jeruk purut akan ikut terbawa. Selanjutnya pipa penyalur disalurkan melalui ketel ketiga yang berfungsi sebagai kondensor. Setelah mengalami proses kondensasi, campuran minyak dan air akan keluar dari kondensor. Dengan adanya perbedaan berat jenisnya maka air dapat dipisahkan dari minyak. Rangkaian alat destilasi uap ditunjukkan pada Gambar 1.

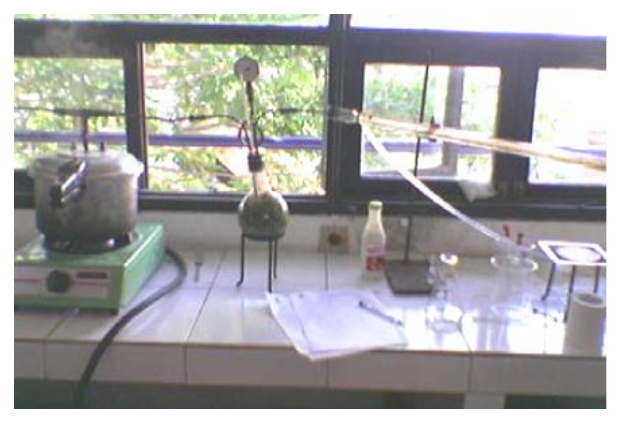

\section{Gambar 1. Rangkaian Alat Destilasi Uap}

Pada metode destilasi air, bahan yang akan disuling mengalami kontak langsung dengan air mendidih. Bahan tersebut mengapung diatas air atau terendam secara sempurna tergantung dari bobot jenis dan jumlah bahan yang disuling. Air dipanaskan dengan metode pemanasan yang biasa dilakukan, yaitu dengan panas langsung, mantel uap, pipa uap melingkar tertutup, atau dengan memakai pipa uap melingkar terbuka atau berlubang.

Ciri khas dari metode ini adalah kontak langsung antara bahan dengan air mendidih. Beberapa jenis bahan (misalnya bubuk buah badam, bungan mawar, dan orange blossoms) harus disuling dengan metode ini, karena bahan harus tercelup dan dapat bergerak bebas dalam air mendidih. Jika disuling dengan metode uap langsung, bahan ini akan merekat dan membentuk gumpalan besar yang kompak, sehingga uap tidak dapat berpenetrasi kedalam bahan. Rangkaian alat destilasi air ditunjukkan pada Gambar 2.

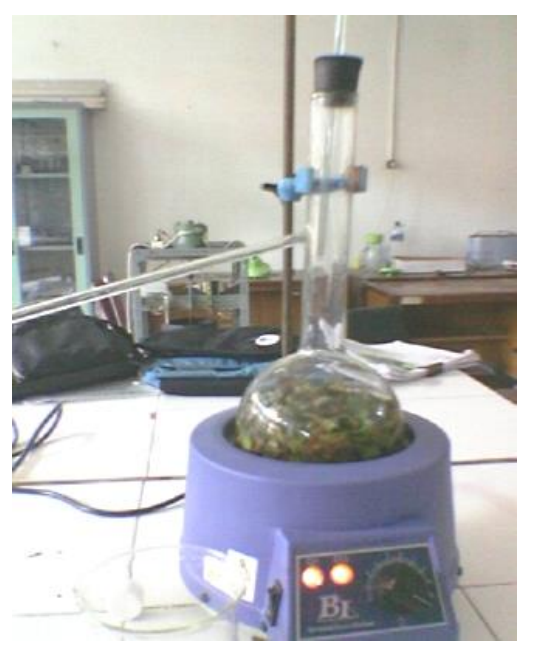

\section{Gambar 2. Rangkaian Alat Destilasi Air}

Proses ekstraksi dilakukan dengan cara memasukkan bahan yang akan diekstraksi ke dalam ketel ekstraktor khusus dan kemudian 
ekstraksi berlangsung secara sistematik pada suhu kamar, dengan menggunakan pelarut organik. Pelarut n-heksan akan berpentrasi ke dalam bahan dan melarutkan minyak atsiri beserta beberapa jenis lilin dan albumin serta zat warna. Larutan tersebut selanjutnya didinginkan dalam kondensor dan minyak dipekatkan dalam suhu rendah. Setelah pelarut teruapkan maka diperoleh minyak atsiri dalam konsentrasi pekat. Rangkaian alat ekstraksi ditunjukkan pada Gambar 3.

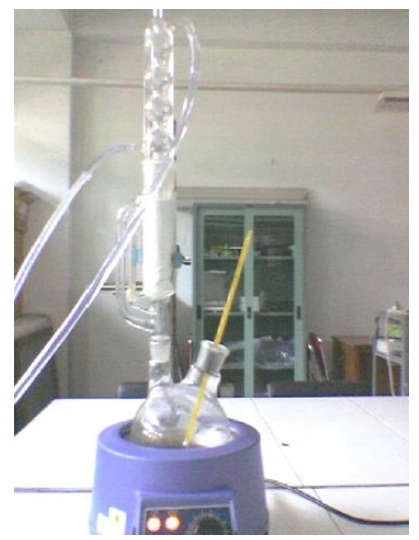

\section{Gambar 3. Rangkaian Alat Ekstraksi}

\section{HASIL DAN PEMBAHASAN}

Penyulingan adalah proses pemisahan komponen yang berupa cairan atau padatan dari 2 macam campuran atau lebih berdasarkan perbedaan titik uapnya dan proses ini dilakukan terhadap minyak atsiri yang tidak larut dalam air.

Penyulingan bahan mempunyai hubungan erat dengan proses difusi, terutama dengan peristiwa osmosis. Dalam penyulingan uap dan penyulingan air tidak terjadi penetrasi oleh uap ke dalam sel membran yang kering. Penyulingan menciptakan kondisi yang baik untuk proses osmosis minyak, karena suhu tinggi dari pergerakan air yang disebabkan oleh kenaikan suhu dalam ketel penyuling mempercepat proses difusi. Dalam keadaan seperti ini seluruh minyak atsiri yang terkandung dalam jaringan tanaman akan terekstrak (Guenther, E,1987).

Sedangkan proses pengambilan minyak atsiri daun jeruk purut dengan metode ekstraksi pelarut menguap cukup sederhana yaitu dengan cara memasukkan bahan yang akan diekstraksi ke dalam ketel ekstraktor khusus dan kemudian ekstraksi berlangsung secara sistematik pada suhu kamar, dengan menggunakan pelarut organik. Pelarut akan berpentrasi ke dalam bahan dan melarutkan minyak atsiri beserta beberapa jenis lilin dan albumin serta zat warna.

Larutan tersebut selanjutnya didinginkan dalam kondensor dan minyak dipekatkan dalam suhu rendah. Setelah pelarut teruapkan maka diperoleh minyak atsiri dalam konsentrasi pekat. Dibandingkan dengan mutu minyak atsiri dari hasil penyulingan maka minyak hasil ekstraksi dengan menggunakan pelarut lebih pekat. Hal ini dikarenakan dalam proses ekstraksi zat yang terikut dalam pelarut bukan hanya minyak tetapi juga zat-zat yang lain seperti parafin dan pigmen warna (Guenther, E,1987)

Pelarut yang digunakan dalam penelitian ini menggunakan pelarut $n$ - heksan yang memiliki titik didih $69^{\circ} \mathrm{C}$ karena merupakan jenis pelarut menguap yang tepat untuk mengekstrak minyak atsiri dengan bahan baku daun. Pelarut ini dianggap tepat karena dapat melarutkan semua minyak yang terkandung dengan cepat dan sempurna dan sedikit mungkin melarutkan bahan seperti lilin, pigmen, mempunyai titik didih yang cukup rendah, agar pelarut mudah diuapkan tanpa menggunakan suhu tinggi namun titik didih pelarut tadi tidak boleh terlalu rendah, karena hal ini akan mengakibatkan hilangnya sebagian pelarut akibat penguapan. n-heksan juga tidak larut dalam air dan bersifat inert, sehingga tidak bereaksi dengan komponen minyak (Guenther, E, 1987)

Dengan proses pengambilan minyak yang berbeda-beda maka mutu, kualitas dan kuantitas juga berbeda-beda untuk masing-masing proses. Suatu proses dapat disebut sesuai untuk digunakan bukan hanya proses yang menghasilkan rendemen minyak paling tinggi tetapi proses tersebut juga harus bias menghasilkan minyak dengan kualitas yang baik. Kualitas minyak daun jeruk purut dipengaruhi oleh kadar geraniol dan sitronelal yang mempengaruhi kekuatan aroma minyak daun jeruk purut.

Dalam percobaan ini proses pengambilan yang dibandingkan adalah proses penyulingan dengan menggunakan destilasi uap, destilasi uap dan ekstraksi menggunakan pelarut nheksan. Dari hasil percobaan ternyata lama penyulingan dan proses pengambilan memberi pengaruh yang sangat nyata terhadap jumlah rendemen minyak atsiri daun jeruk purut hal ini dapat dilihat pada Gambar 4. 


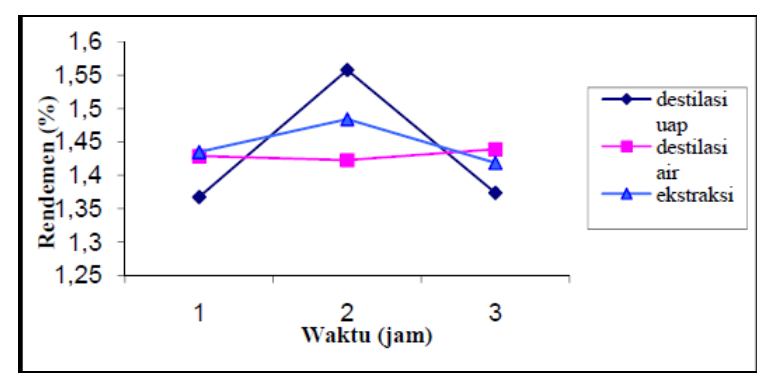

Gambar 4. Kurva hubungan antara pemilihan metode, waktu terhadap jumlah rendemen yang dihasilkan.

Perbedaan hasil percobaan ini disebabkan adalah perbedaan kondisi operasi dan perlakuan terhadap bahan yang akan diambil kandungan minyak atsirinya. Rendemen minyak dengan proses destilasi uap lebih tinggi dibandingkan dengan proses destilasi air karena uap yang berasal dari ketel uap memiliki tekanan dan suhu yang lebih tinggi sehingga dapat mempercepat proses difusi dan osmosis minyak atsiri dari daun jeruk purut.

Sedangkan proses pengambilan dengan menggunakan ekstraksi menghasilkan rendemen minyak yang lebih rendah daripada proses destilasi uap hal ini disebabkan karena pada proses ekstraksi menggunakan pelarut yang mudah menguap dan prosesnya lebih panjang dan sebagian minyak teruapkan pada saat pemisahan minyak dengan pelarut nheksan menggunakan dengan proses destilasi. Selain itu semakin lama waktu dan semakin tinggi suhu yang digunakan dalam proses eksraksi maka semakin banyak kemungkinan minyak atsiri yang menguap.

Bila dilihat dari masing-masing perlakuan dapat disimpulkan, semakin lama waktu penyulingan maka rendemen yang diperoleh semakin tinggi sampai lama penyulingan tertentu rendemen ini tidak akan bertambah. Pengambilan dengan proses destilasi uap lama penyulingan 2 jam menghasilkan rendemen yang tertinggi yaitu $1,557 \%$. pada lama destilasi uap 3 jam tidak menambah rendemen minyak, hal ini disebabkan pada lama penyulingan 3 jam tidak ada lagi sel-sel minyak yang dapat disuling.

Dengan menggunakan proses destilasi air waktu maksimal untuk menghasilkan rendemen minyak paling tinggi adalah 3 jam yang menghasilkan rendemen minyak $1,439 \%$ dan dengan proses ekstraksi waktu maksimum menghasilkan rendemen minyak paling tinggi adalah dengan waktu 2 jam dengan rendemen
1,484\%. Semakin disuling sampai batas 2 jam rendemen minyak akan semakin naik, hal ini disebabkan oleh semakin banyaknya panas yang diterima oleh bahan untuk menguapkan sel-sel minyak dari bahan dan semakin banyak uap yang berhubungan dengan sel-sel minyak dalam jaringan bahan, sehingga minyak yang terekstraksi semakin banyak. Di samping itu semakin lama penyulingan maka semakin banyak panas yang diterima dan proses diffusi akan meningkat sehingga proses penyulingan semakin dipercepat (Rusli, 1979).

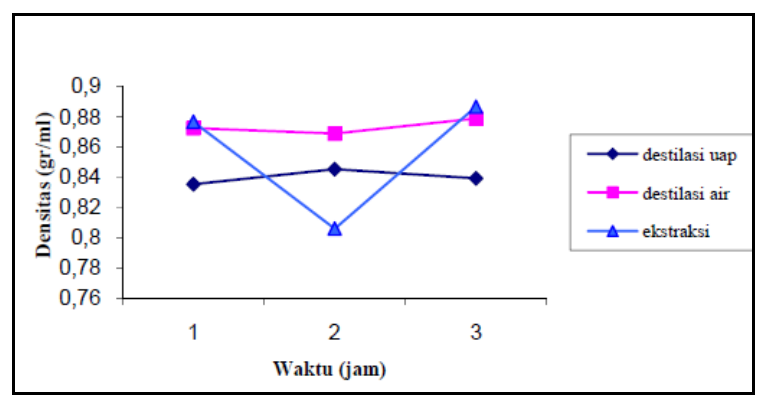

Gambar 5. Kurva hubungan antara pemilihan metode, waktu terhadap densitas miyak daun jeruk purut yang dihasilkan.

Dari Gambar 5 dapat dilihat perbedaan densitas minyak daun jeruk purut karena pengaruh lama dan proses pengambilan. Dari grafik tersebut dapat dilihat bahwa pada proses penyulingan destilasi air dan destilasi uap maka semakin lama waktu penyulingan akan naik sampai batas waktu 2 jam dan kemudian turun. Semakin naiknya densitas sampai batas waktu 2 jam adalah disebabkan oleh semakin naiknya kadar geraniol dan sitronelal sampai lama penyulingan 2 jam. Geraniol dan sitroneal merupakan petunjuk kemurnian minyak daun jeruk purut. Jadi semakin banyak kandungan geraniol dan sitronelal minyak tersebut akan semakin murni (Anonimus, 1978).

Penyebab bau utama pada minyak daun jeruk purut adalah sitronelal dan geraniol, yang merupakan bahan dasar untukpembuatan parfum, oleh karena itu minyak daun jeruk purutdengan kadar sitronelal tinggi akan lebih baik kualitasnya. Jenisminyak yang demikian akan diperoleh dari fraksi pertamapenyulingan. Khususnya di Indonesia minyak daun jeruk purutyang diperdagangkan diperoleh dengan cara penyulingan daunjeruk purut Citrus hystrix. Minyak daun jeruk purut Indonesiadigolongkan dalam satu jenis mutu utama dengan nama"Combava Petitgrain Oil". 
Standar mutu minyak daun jeruk purut untuk kualitas eksport dapat dianalisa menurut kriteria fisik yaitu berdasarkanwarna, bobot jenis, indeks bias, ataupun secara kimia berdasarkan total geraniol dan sitronelal (Kapoor dan Krishan, 1977)

Dalam penelitian ini analisa kandungan geraniol dan sitronelal dilakukan dengan proses titrasi menggunakan $\mathrm{HCl}$ berdasarkan SNI 060027-1987 untuk geraniol dan berdasarkan SNI 06-0026-1987 untuk sitronelal. Dari hasil penelitian ternyata lama dan cara pengambilan minyak atsiri daun jeruk purut, mempengaruhi kandungan geraniol yang dihasilkan hal ini dapat dilihat pada Gambar 6. Dari grafik tersebut dapat dilihat perbedaan nilai total geraniol dari masing-masing perlakuan, total geraniol dari perlakuan destilasi uap adalah $0,91 \%$ sampai $1,36 \%$; dengan destilasi air $0,87 \%$ sampai $1,31 \%$ dan dengan ekstraksi $1,30 \%$ sampai $2,15 \%$. Dari kisaran tersebut maka minyak daun jeruk purut dalam penelitian ini mengandung total geraniol yang mencukupi untuk standart eksport minimal $0,4 \%$ (Departemen Perdagangan, 1974).

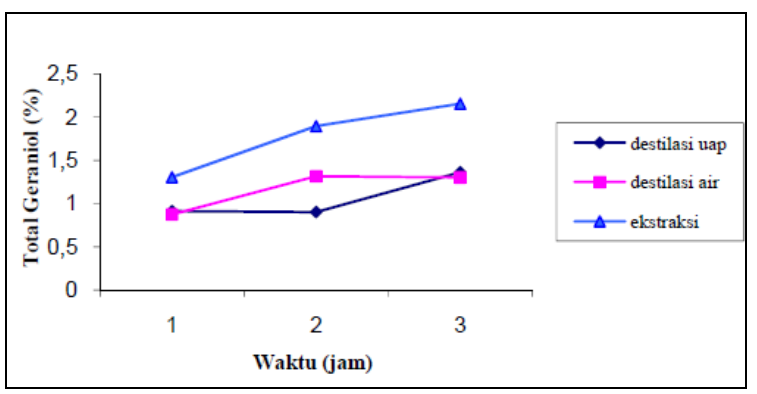

\section{Gambar 6. Kurva hubungan antara pemilihan metode, waktu terhadap kandungan geraniol minyak daun jeruk purut yang dihasilkan.}

Perlakuan sebelum penyulingan seperti perajangan dan pelayuan sangat mempengaruhi total geraniol. Perajangan dapat menyebabkan terdifusinya molekul minyak ke permukaan bahan sehingga minyak ikut menguap bersama air. Selain itu proses pengambilan minyak akan mempengaruhi total geraniol. Pada proses destilasi uap, destilasi air, dan ekstraksi uap, air dan pelarut mendidih berkontak langsung dengan bahan. Pada suhu tinggi geraniol akan terdekomposisi dan terpolimerisasi sehingga mengurangi total geraniol (Guenther, E, 1987)

Bila dilihat dari masing - masing perlakuan, semakin lama waktu penyulingan maka total geraniol semakin tinggi. Hal ini disebabkan oleh semakin banyaknya panas yang diterima oleh bahan untuk menguapkan sel-sel minyak dari bahan sehingga total geraniol akan semakin tinggi. Pada proses destilasi air dengan waktu 3 jam total geraniol akan turun. Hal ini disebabkan karena bahan yang terlalu lama dipanasi sehingga menyebabkan geraniol akan terdekomposisi menjadi senyawa-senyawa isopren. Disamping itu, karena geraniol merupakan komponen volatil oil maka pada pemanasan yang lama akan menyebabkan geraniol hilang atau terpolimerisasi yang menghasilkan polimer-polimer dengan berat molekul yang lebih tinggi (Ketarendan dan .Jatmiko, 1978).

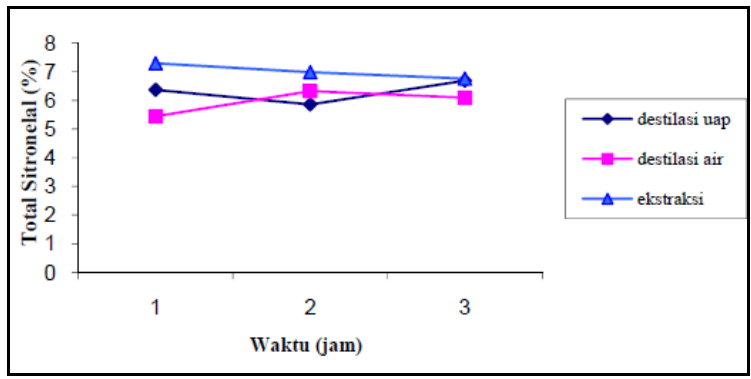

\section{Gambar 7. Kurva hubungan antara pemilihan metode, waktu terhadap kandungan sitronelal minyak daun jeruk purut yang dihasilkan.}

Perbedaan nilai total sitronelal dari masingmasing perlakuan penelitian dapat dilihat dalam Gambar 7. Dari grafik tersebut dapat dilihat perbedaan nilai total sitronelal dari masingmasing perlakuan. Total sitronelal dari perlakuan destilasi uap adalah $5,86 \%$ sampai $6,69 \%$; dengan destilasi air 5,44\% sampai $6,32 \%$ dan dengan ekstraksi $6,76 \%$ sampai $7,29 \%$. Dalam literatur nilai total sitronelal untuk kualitas eksport minimum harus 6,5\% (Departemen Perdagangan,1974).

Kenaikan total kadar sitronelal sampai batas proses pengambilan selama 2 jam, seperti halnya juga total sitonelal, yaitu disebabkan oleh smakin banyaknya panas yang diterima oleh bahan untuk menguapkan sel-sel minyak dari bahan sehingga total sitronelal akan semakin tinggi. Pada proses pengambilan dengan waktu 3 jam total sitronelal akan turun. Seperti halnya geraniol, sitronelal akan terdekomposisi menjadi senyawa-senyawa isopren. Dan karena sitronelal merupakan komponen volatil oil maka pada pemanasan 
yang lama menyebabkan sitronelal hilang atau terpolimerisasi yang menghasilkan polimerpolimer dengan berat molekul yang lebih tinggi (Ketarendan dan Jatmiko, 1978).

Jika kita bandingkan nilai total sitronelal dengan nilai total geraniol maka nilai kadar sitronelal lebih cepat mengalami penurunan yaitu pada perlakuan destilasi air dan ekstraksi dengan waktu 2 jam. Hal ini disebabkan sitronelal mempunyai titik didih yang lebih rendah $\left(205^{\circ} \mathrm{C}\right)$ bila dibandingkan dengan titik didih geraniol $\left(230^{\circ} \mathrm{C}\right)$. Sehingga sitronelal lebih mudah menguap (Ketaren, 1985).

Kualitas minyak atsiri dari daun jeruk purut hasil percobaan ini bila dibandingkan dengan standart SNI untuk eksport tersaji pada Tabel 1:

Tabel 1. Perbandingan Mutu Minyak Atsiri Daun Jeruk Purut Hasil Percobaan dengan Standart Eksport

\begin{tabular}{|c|c|c|c|c|}
\hline \multirow[t]{2}{*}{ Karakteristik } & \multicolumn{3}{|c|}{ Hasil Percobaan } & \multirow{2}{*}{$\begin{array}{c}\text { Standart } \\
\text { eksport }\end{array}$} \\
\hline & $\begin{array}{l}\text { Destilasi } \\
\text { Uap }\end{array}$ & $\begin{array}{l}\text { Destilasi } \\
\text { Air }\end{array}$ & Ekstraksi & \\
\hline $\begin{array}{l}\text { Rendemen } \\
(\%)\end{array}$ & $\begin{array}{l}1,336- \\
1,522\end{array}$ & $\begin{array}{l}1,390- \\
1,406\end{array}$ & $\begin{array}{l}1,386- \\
1,450\end{array}$ & - \\
\hline $\begin{array}{l}\text { Densitas } \\
\left(25^{\circ} \mathrm{C}\right)\end{array}$ & $\begin{array}{l}0,835- \\
0,845\end{array}$ & $\begin{array}{l}0,868- \\
0,878\end{array}$ & $\begin{array}{l}0,806- \\
0,876\end{array}$ & $\begin{array}{ll}0,82 & - \\
0,892 & \end{array}$ \\
\hline Warna & kuning & $\begin{array}{l}\text { kuning } \\
\text { pucat }\end{array}$ & $\begin{array}{l}\text { kuning } \\
\text { pucat }\end{array}$ & $\begin{array}{l}\text { kuning } \\
\text { pucat } \\
\text { sampai } \\
\text { kehijauan }\end{array}$ \\
\hline $\begin{array}{l}\text { Kadar } \\
\text { Geraniol (\%) }\end{array}$ & $0,93-1,39$ & $\begin{array}{l}0,89- \\
1,35\end{array}$ & $\begin{array}{l}1,34- \\
2,21\end{array}$ & $\begin{array}{l}\text { Min } 0,4 \\
\text { SNI } \\
06-0027- \\
1987\end{array}$ \\
\hline $\begin{array}{l}\text { Kadar } \\
\text { Sitronelal } \\
(\%)\end{array}$ & $5,86-6,69$ & $\begin{array}{l}5,44- \\
6,32\end{array}$ & $\begin{array}{l}6,76- \\
7,29\end{array}$ & $\begin{array}{l}\text { Min 6,5 } \\
\text { SNI } \\
06-0026- \\
1987\end{array}$ \\
\hline
\end{tabular}

Dari tabel diatas dapat diketahui minyak atsiri hasil percoban untuk proses pengambilan destilasi uap dan ekstraksi telah memenuhi standart eksport. Hasil persentase kandungan minyak daun jeruk purut bervariasi yang disebabkan oleh beberapa faktor seperti kondisi penyimpanan, metode pengambilan (Chanthaphon dkk, 2008), keadaan tanah dan iklim tempat tumbuh (Jamal, 2009)

\section{KESIMPULAN}

Lama penyulingan dan cara pengambilan minyak atsiri dari daun jeruk purut memberi pengaruh nyata terhadap rendemen, densitas, total geraniol dan total sitronelal. Lama penyulingan yang terlalu lama (di atas 2,5 jam) dengan jumlah bahan 50 gr akan menurunkan mutu rendemen yang dikehendaki. Minyak daun jeruk purut dalam penelitian ini memenuhi standart mutu eksport, menghasilkan rendemen 1,336 - 1,522 dengan kandungan geraniol 0,89 $2,21 \%$ dan sitronelal 5,44 - 7,29\%.

\section{DAFTAR PUSTAKA}

Anonimous, 1974. Direktorat Standardisasi, Normalisasasi Dan Pengendalian Mutu, Departemen Perdagangan Dan Koperasi. 1978. Analisa Total Geraniol Pada Minyak Sereh Wangi, Departemen Perdagangan

Ayusuk, S., Sunisa, S., Paiboon, $\mathrm{T}$ dan Worapong, U. 2009. Effect of Heat Treatment on Antioxidant Properties of Tom-Kha Paste and Herbs/Spices Used in Tom-Kha Paste. Kasetsart J. (Nat. Sci.) 43 : $305-312$.

Chanthaphon, S., Chanthachum, S. dan Hongpattarakere, T, 2008. Antimicrobial activities of essential oils and crude extracts from tropical citrus spp. Against food related microorganisms. 30(Suppl.1): 125-131.

Guenther, E, 1987. Minyak Atsiri. Jilid I, Universitas Indonesia Press, Jakarta

Jamal, Y, 2009. Komposisi kimia minyak atsiri Melodorum cylindricum (Maing. ex Hook.f and Thoms), Litsea firma Callistemon lanceolatus D.C. (6): 721-730.

Kapoor, L. D [and] Ram Krishan, 1977. Advances In Essential Oil Industry, Held At Kanpur.

Ketaren, S [dan] B. Djatmiko, 1878. Minyak Atsiri Bersumber Dari Daun, Departemen Teknologi Hasil Pertanian, Fatemeta IPB Bogor.

Ketaren, S dan B. Djatmiko, 1978. Minyak Atsiri Bersumber Dari Bunga Dan Buah, Departemen Teknologi Hasil Pertanian, Fatemeta IPB, Bogor.

Ketaren, S, 1985. Pengantar Teknologi Minyak Atsiri, Balai Pustaka, Jakarta.

Koswara, S. 2011. Menyuling dan menepungkan minyak atsiri daun jeruk purut.http://www.ebookpangan.com/ARTI KEL/MENYULING\%20DAN\%20MENE PUNGKAN\%20MINYAK\%20ASIRI.pdf. [28 Maret 2019].

Nanasombat, S dan Pana, L, 2005. Antibacterial Activity of Crude Ethanolic Extracts and Essential Oils of Spices Against Salmonellae and Other Enterobacteria. KMITL Sci. Tech. J. Vol. 5 No. 3 Jul. 
Rusli, S, 1977. Konstruksi Unit Penyulingan Sereh Wangi, Sereh Dapur Dan Cengkeh, Lembaga Penelitian Tanaman Industri. 